\title{
Does the Timing of lleostomy Closure Does not Impact the Development of Complications During lleostomy and After Its Reversal? A Retrospective Study in A Single Colorectal Center
}

\author{
Illeostomi Kapamanın Zamanlaması Illeostomi Varlığında ve Kapanması Sonrasında \\ Komplikasyonların Gelişimini Etkiler Mi? Tek Bir Kolorektal Merkeze Ait Retrospektif Bir Çalışma
}

\author{
(1) Mehmet Arif Usta, (1) Arif Burak Çekiç \\ Karadeniz Technical University Faculty of Medicine, Department of General Surgery, Trabzon, Turkey
}

\section{Abstract}

Objectives: A temporary diverting loop ileostomy is often performed with sphincter-preserving surgery for rectal cancer. However, optimal timing for the reversal of ileostomy is a challenging issue concerning the different cut-off periods. We aimed to evaluate the association between timing of closure and development of complications during ileostomy and after its closure.

Materials and Methods: Between January 2016 and August 2020, patients who underwent ileostomy and ileostomy closure associated with the sphincter-preserving surgery for rectum adenocarcinoma were retrospectively analyzed. Ileostomy creation for rectovaginal fistula, restorative proctocolectomy, and emergent surgery for left-sided colonic tumors, and patients without ileostomy closure for any cause were excluded. Patient demographics and clinical variables were recorded. According to ileostomy closure time, the patients were divided into two groups as $<6$ and $\geq 6$ months. Complications associated with ileostomy and postoperative complications after ileostomy reversal were analyzed regarding the closure time.

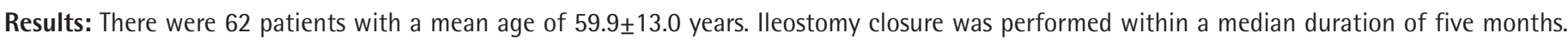
Ileostomy-related complications developed in 14 patients (22.6\%). The mean age was significantly higher in patients with complications ( $p=0.027$ ). In 24 patients (38.7\%), there were ileostomy reversal-related complications. Elderly female patients with higher body mass index and more comorbid diseases were more likely to have complications following ileostomy closure $(p<0.05)$. Although the duration of ileostomy in the complicated patients was lower than in the non-complicated patients (five vs. six months), there was no significant difference ( $p=0.535$ ). There was no significant impact of the grouping based on the timing of ileostomy closure as $<6$ and $\geq 6$ months on the development of complications ( $p>0.05$ ).

Conclusion: Timing of ileostomy closure did not influence the ileostomy-related complications and postoperative complications. Age was a significant variable for the development of complications. Female sex, obesity, and comorbidity were associated only with ileostomy reversal-related complications.

Key Words: Ileostomy, Rectum Cancer, Postoperative Complications

\section{Öz}

Amaç: Rektum kanseri için uygulanan sfinkter koruyucu cerrahiye genellikle geçici bir saptırıcı ileostomi de eşlik etmektedir. Bununla birlikte ileostomi kapama operasyonunun zamanlaması kapama için farklı sürelerin önerildiği tartışmalı bir konudur. Bu yazıda ileostomi süresince ve kapatıldıktan sonra karşılaşılan komplikasyonların kapama zamanlaması ile arasındaki ilişkiyi değerlendirmeyi amaçladık.

Gereç ve Yöntem: Ocak 2016-Ağustos 2020 tarihleri arasında rektum adenokarsinomu nedeniyle sfinkter koruyucu cerrahi ve ileostomi uygulanan ve ileostomisi daha sonra kapatılan hastalar geriye dönük olarak incelendi. Rektovajinal fistül, restoratif proktokolektomi ve acil girişim gerektiren sol kolon tümörleri nedeniyle ileostomi açılan hastalar ve herhangi bir nedenle ileostomi kapatılmamış hastalar çalışmaya dahil edilmedi. Hastaların demografik özellikleri ve klinik değişkenler kaydedildi. İleostomi kapanma süresine göre hastalar < 6 ve $\geq 6$ ay olmak üzere iki gruba ayrıldı. İleostomi ile ilişkili komplikasyonlar ve ileostomi kapanması sonrası karşılaşılan postoperatif komplikasyonlar ileostomi kapanma sürelerine göre incelendi.

Address for Correspondence/Yazışma Adresi: Mehmet Arif Usta,

Karadeniz Technical University Faculty of Medicine, Department of General Surgery, Trabzon, Turkey

Phone: +90 5326236035 E-mail: ustausta@windowslive.com ORCID ID: orcid.org/0000-0003-2460-4741

Received/Geliş Tarihi: 28.10.2020 Accepted/Kabul Tarihi: 01.03.2021

๑Copyright 2021 Ankara University Faculty of Medicine

Journal of Ankara University Faculty of Medicine is published by Galenos Publishing House.

All content are under CC BY-NC-ND license. 


\section{$\ddot{0 ̈ z}$}

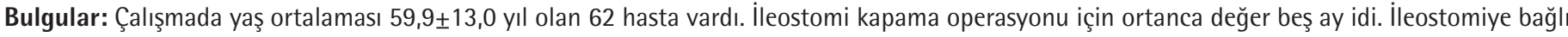
komplikasyonlar 14 hastada $(\% 22,6)$ gelişti. Ortalama yaş komplikasyon gelişen hastalarda anlamlı derecede daha yüksekti $(p=0,027)$. Hastaların 24 'ünde $(\% 38,7)$ ileostomi kapama ile ilişkili komplikasyonlar tespit edildi. Daha yüksek vücut kitle indeksi ve daha fazla komorbid hastalığı olan yaşlı kadın hastalarda ileostomi kapatıldıktan sonra komplikasyon görülme olasılığı daha yüksekti $(p<0,05)$. Komplikasyon gelişen hastalarda ileostomi süresi komplike olmayan hastalara göre daha kısa olmasına rağmen (beş aya karşı altı ay) anlamlı bir fark yoktu ( $p=0,535$ ). İleostomi kapama zamanlamasına göre $<6$ ve $\geq 6$ ay olarak yapılan gruplamanın komplikasyon gelişimine anlamlı bir etkisi yoktu $(p>0,05)$.

Sonuç: Illeostomi kapamanın zamanlaması ileostomiye bağlı komplikasyonları ve postoperatif komplikasyonları etkilememiştir. Yaş, komplikasyonların gelişimi için önemli bir değişkendi. Kadın cinsiyet, obezite ve komorbidite sadece ileostomi kapamaya bağlı komplikasyonlarla ilişkili bulundu.

Anahtar Kelimeler: İleostomi, Rektum Kanseri, Postoperatif Komplikasyonlar

\section{Introduction}

A temporary diverting loop ileostomy is often created to protect the anastomosis during the sphincter-preserving surgery for rectal cancer (1-3). An ileostomy is usually reversed after completion of adjuvant therapies leading to an approximate time of 8-12 weeks. Although ileostomy has reduced the rates of anastomotic leakage and the number of reoperations, ileostomy-related complications and complications following ileostomy closure are considerable $(1,2)$. A variety of ileostomyrelated complications can be seen in $47 \%$ of the patients with ileostomy (4-6). Ileostomy closure is also associated with significant morbidity in almost half of the patients $(3,6-8)$.

It has been recommended that the ileostomy closure should be performed as early as possible, considering its complications (1-4). Although early ileostomy closure's safety and feasibility have been reported $(3,4,7,9)$, higher complications in association with early closure were seen in other studies (10-12). Besides, different cut-off periods ranging from one to six months are used to define early and late ileostomy closure $(4,9,13)$. Thus, the optimal timing for the reversal of ileostomy is a challenging issue.

In this study, we aimed to evaluate the effect of timing of ileostomy closure on the development of ileostomy-related and ileostomy reversal-related complications in a single colorectal surgery center.

\section{Materials and Methods}

\section{Study}

This study was a retrospective analysis of all consecutive patients who underwent ileostomy and ileostomy closure associated with sphincter-preserving surgery for rectal adenocarcinoma at Karadeniz Technical University Faculty of Medicine, Department of General Surgery between January 2016 and August 2020. The local ethical committee approved the study (Ethical Committee for Clinical Studies, Karadeniz Technical University, Faculty of Medicine, 2020/273). The study was performed according to the Declaration of Helsinki. The patients' written consent could not be taken due to the retrospective design of the study and the anonymity of data.

\section{Patients and Variables}

All patients with temporary diverting loop ileostomy $(n=76)$ were initially evaluated. Ileostomy creation for rectovaginal fistula $(n=2)$ and restorative proctocolectomy $(n=2)$ and emergent surgery for left-sided colonic tumors $(n=4)$ were not included. The patients without ileostomy closure for any cause $(n=6)$ were also excluded. The index surgery was performed for middle (tumors located within 6 to $10 \mathrm{~cm}$ from the anal verge) or distal (tumors located within $\leq 5 \mathrm{~cm}$ from the anal verge) rectal adenocarcinoma, treated with neoadjuvant therapy, followed by low anterior or very low anterior resection for curative intent. Finally, 62 patients with ileostomy and its reversal were included in the study (Figure 1). Patients requiring conversion to laparotomy for reversal of ileostomy were not excluded.

Patient demographics, including age, sex, body mass index (BMI), presence of comorbidities, smoking history, the American Society of Anesthesiologists (ASA) score, features of the index rectal surgery, and tumor characteristics were collected. Operative and postoperative outcomes, including duration of ileostomy (interval between the primary operation and reversal of ileostomy), type of anastomosis, time to oral feeding, length of hospital stay after ileostomy closure, were recorded using a prospectively held colorectal cancer database.

\section{Surgical Techniques}

Loop ileostomy was created at the right lower quadrant of the patients. Repair of diverting ileostomy (reversal of ileostomy) was planned initially after the completion of adjuvant therapy. In selected cases, early closure before or during the adjuvant treatment was performed.

Before the closure of ileostomy, each anastomosis was examined via endoscopically to confirm the absence of leakage, stenosis, and fistula. lleostomy closure was performed under general anesthesia. After intravenous administration of prophylactic antibiotics (cefotaxime, $1.0 \mathrm{~g}$, and metronidazole 


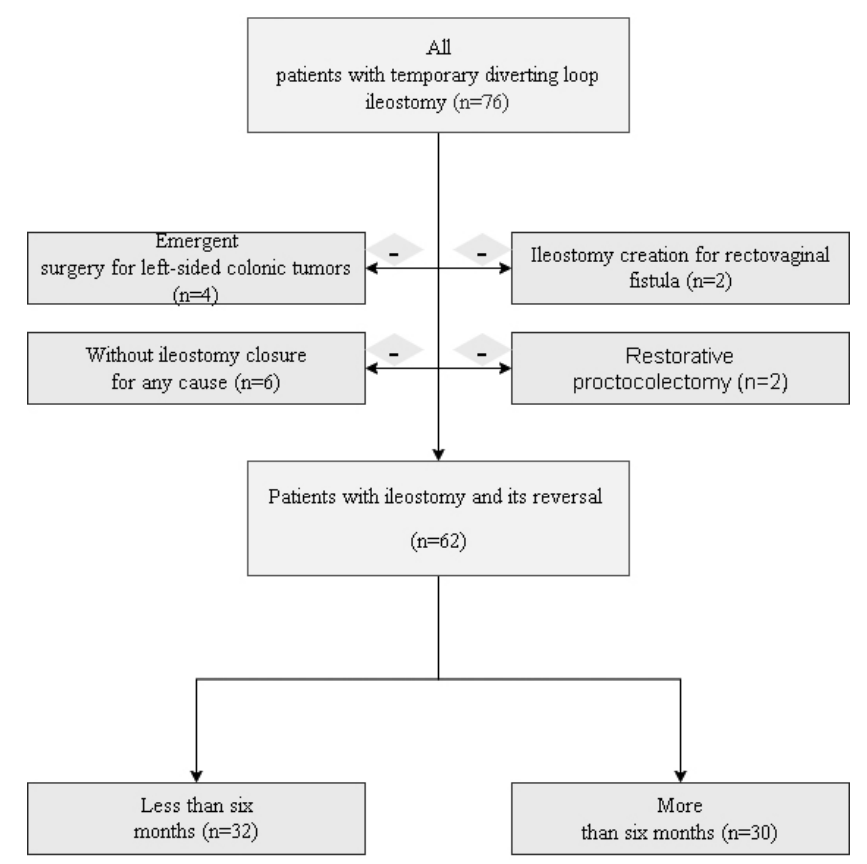

Figure 1: Flow chart of the study

$0.5 \mathrm{mg}$ ), a circumstomal incision was used to mobilize the ileal segments of ileostomy. The end-to-end or side-to-side anastomosis was performed either by hand-sewn approach or using stapled closure depending on the discretion of the attending surgeon. The posterior and anterior rectus sheaths were separately closed to minimize the risk of prolapsus and incisional hernia.

\section{Follow-up}

All patients were examined at the outpatient clinics every month. The timing for ileostomy closure was determined based on the surgeon's preference and patients' needs.

\section{Outcome Measures}

lleostomy-related and ileostomy reversal-related complications were analyzed in association with the timing of closure. According to ileostomy closure time, the patients were also divided into two groups: less than six months and more than six months (9).

Any medical or surgical complication within the first 30 days after ileostomy closure was recorded and graded based on the Clavien-Dindo classification (9). High-output drainage ( $>500 \mathrm{~mL} /$ day), stomal ulceration, acute renal failure, prolapsus, and parastomal hernia were defined as the ileostomy-related complications. Anastomotic leakage, bowel obstruction/ ileus, intraabdominal abscess, and wound complications were regarded as the postoperative surgical complications after ileostomy closure (14).
Postoperative paralytic ileus was defined as the dilation of the small bowel segments that were confirmed radiologically in association with failure to tolerate oral intake, absent or sluggish bowel sounds remained, and absence of bowel movements during at least the initial three days after the operation. Any purulent discharge from the surgical wounds associated with hyperemia of the incision was defined as surgical site infections.

\section{Statistical Analysis}

Statistical analysis was performed using a commercially available statistical software package (SPSS Inc., Chicago, IL). The Kolmogorov-Smirnov or Shapiro-Wilk tests were applied to determine the normal distribution of continuous variables. Mean \pm standard deviation and median with interquartile range (IQR) of 25\% and 75\% (IOR 01-03) were used to express continuous variables with and without normal distribution. Categorical variables were expressed as frequencies and percentages. The Pearson chi-square and Fisher's exact tests were used for categorical variables. The Mann-Whitney U test was applied to compare continuous variables without normal distribution. The t-test and One-Way analysis of variance (ANOVA) were used to compare continuous variables with the normal distribution. A $p$-value of $<0.05$ was considered significant.

\section{Results}

The mean age of the patients was $59.9 \pm 13.0$ years. There were $36(58.1 \%)$ males and $26(41.9 \%)$ females. In more than half of the patients (54.3\%), the ASA grade was 3. Demographic and clinical features of the study group are given in Table 1.

After the median interval of 5 months (4-7 months), ileostomy closure was performed. Ileostomy-related complications developed in 14 patients (22.6\%). The details are summarized in Table 2. High-output drainage and stomal ulceration were the most commonly seen complications (17.7\%). The mean age of the patients with ileostomy-related complications was significantly higher than that of the patients without complications $(p=0.027)$. The median duration of ileostomy closure was six months in the complicated patients, whereas five months in the non-complicated ones $(p=0.564)$. There was no significant impact of other demographic and clinical features on the development of ileostomy-related complications ( $p>0.05$ for all) (Table 3).

The stapled approach for ileostomy closure was used in most of the patients (85.5\%). In 24 patients (38.7\%), there were ileostomy reversal-related complications. Clavien-Dindo grades $2(16.1 \%)$ and $1(14.5 \%)$ were the most common types. The clinical features concerning the ileostomy closure are given in Table 4. Wound infection (19.4\%), and non-surgical complications (12.9\%) were more frequently seen in the study group (Table 5). 


\begin{tabular}{|c|c|c|}
\hline Variable & & Value \\
\hline Age $\left(\right.$ year) ${ }^{+}$ & & $59.9 \pm 13.0$ \\
\hline \multirow{2}{*}{$\operatorname{Sex}^{+}$} & Female & $26(41.9)$ \\
\hline & Male & $36(58.1)$ \\
\hline \multicolumn{2}{|l|}{ BMI $\left(\mathrm{kg} / \mathrm{m}^{2}\right)^{+}$} & $26.2 \pm 4.3$ \\
\hline \multirow{3}{*}{ ASA grade $^{\ddagger}$} & 1 & $10(16.1)$ \\
\hline & 2 & $18(29.0)$ \\
\hline & 3 & $34(54.8)$ \\
\hline \multirow{6}{*}{ Comorbidity $^{\ddagger}$} & Yes & $27(43.5)$ \\
\hline & No & $35(56.5)$ \\
\hline & Hypertension & $24(38.8)$ \\
\hline & Coronary artery disease & $5(8.1)$ \\
\hline & Diabetes mellitus & $5(8.1)$ \\
\hline & Renal failure & $5(8.1)$ \\
\hline \multirow{2}{*}{ Smoking ${ }^{\ddagger}$} & Yes & $8(12.9)$ \\
\hline & No & $54(87.1)$ \\
\hline \multirow{2}{*}{ Rectal surgery ${ }^{\ddagger}$} & Open & $44(71.0)$ \\
\hline & Laparoscopic & 18 829.0) \\
\hline \multirow{5}{*}{ T stage $^{\ddagger}$} & 0 & $10(16.1)$ \\
\hline & 1 & $3(4.8)$ \\
\hline & 2 & $2(19.4)$ \\
\hline & 3 & $35(56.5)$ \\
\hline & 4 & $2(3.2)$ \\
\hline \multirow{3}{*}{$\mathrm{N}_{\text {stage }}{ }^{\neq}$} & 0 & $40(64.5)$ \\
\hline & 1 & $13(21.0)$ \\
\hline & 2 & $9(14.5)$ \\
\hline \multirow{4}{*}{ TNM stage $^{\neq}$} & 0 & $9(14.5)$ \\
\hline & 1 & $9(14.5)$ \\
\hline & 2 & $24(38.7)$ \\
\hline & 3 & $20(32.3)$ \\
\hline \multicolumn{2}{|l|}{$\begin{array}{l}\text { Timing of ileostomy } \\
\text { closure (month) }{ }^{\beta}\end{array}$} & $5(4-7)$ \\
\hline \multicolumn{3}{|c|}{$\begin{array}{l}\text { +: Mean } \pm \text { standard deviation, }{ }^{+}: n(\%), \beta: \text { Median (IQR) } \\
\text { IQR: Interquartile range, BMI: Body mass index, ASA } \\
\text { Anesthesiologists }\end{array}$} \\
\hline
\end{tabular}

Age, sex, BMI, and presence of comorbidity were significantly associated with the development of ileostomy reversal-related complications ( $p<0.05$ for all) (Table 6). Elderly female patients with higher BMI and more comorbid diseases were more likely to have complications following ileostomy closure. There was no mortality in the study group. Although the median time from the creation of ileostomy to closure in the complicated patients was lower than the non-complicated patients (five vs. six months), there was no significant difference $(p=0.535)$. Time to oral feeding and length of hospital stay were significantly lower in patients without complications ( $p=0.002$ and $p=0.013$ ).

There was no significant impact of the grouping based on the timing of ileostomy closure as $<6$ and $\geq 6$ months on the development of both ileostomy-related and ileostomy reversalrelated complications ( $p=0.597$ and $p=0.799$ ) (Table 7).

\section{Discussion}

In this study, we did not show the effect of the duration of ileostomy on the development of complications. The age of the patients was significantly associated with the development of both ileostomy-related and ileostomy reversal-related complications. In contrast, elderly obese female patients with comorbid diseases were more prone to developing ileostomy reversal-related complications.

The timing of ileostomy closure has been questioned to identify patients with fully healed anastomoses (6). Different cut-off time limits and different definitions of early or late closure ranging from 8-13 days to 6 months have been used $(4,7,9,10,15-17)$.

Besides, some authors recommended to close the protective ileostomy after or during adjuvant chemotherapy protocols $(3,18)$. As our institutional policy, we have performed the ileostomy reversal operations depending on the patients' clinical situation and desire. In this retrospective study, the median time was five months. So, we analyzed the exact timing as months and the grouping as $<6$ and $\geq 6$ months. Our results showed no impact of timing on the development of complications.

Table 2: Distribution of ileostomy-related complications

\section{Variable}

lleostomy related complications
Yes

No

Complication n (\%)

14 (22.6)

40 (64.5)

High output drainage

$11(17.7)$

Stomal ulceration $11(17.7)$

Renal failure 5 (8.1) $3(4.8)$

Prolapsus 3 (4.8) 


\begin{tabular}{|c|c|c|c|c|}
\hline Variable & & $\begin{array}{l}\text { Patients with complications } \\
(n=22)\end{array}$ & $\begin{array}{l}\text { Patients without } \\
\text { complications }(n=40)\end{array}$ & p \\
\hline Age (year) ${ }^{+}$ & & $64.8 \pm 10.3$ & $57.2 \pm 13.7$ & 0.027 \\
\hline \multirow{2}{*}{$\operatorname{Sex}^{\neq}$} & Female & $9(40.9)$ & $17(42.5)$ & \multirow{2}{*}{1.0} \\
\hline & Male & $13(59.1)$ & 23 (57.5) & \\
\hline BMI $\left(\mathrm{kg} / \mathrm{m}^{2}\right)^{+}$ & & $26.5 \pm 4.3$ & $26.0 \pm 4.4$ & 0.680 \\
\hline \multirow{3}{*}{ ASA grade $^{\ddagger}$} & 1 & $3(13.6)$ & 7 (17.5) & \multirow{3}{*}{0.311} \\
\hline & 2 & $9(40.9)$ & $9(22.5)$ & \\
\hline & 3 & $10(45.5)$ & $24(80.0)$ & \\
\hline \multirow{2}{*}{ Comorbidity $^{*}$} & Yes & $9(40.9)$ & $18(45.0)$ & \multirow{2}{*}{0.795} \\
\hline & No & 13 (59.1) & $22(55.0)$ & \\
\hline \multirow{2}{*}{ Rectal surgery ${ }^{*}$} & Open & $19(86.4)$ & $25(62.5)$ & \multirow{2}{*}{0.078} \\
\hline & Laparoscopic & $3(13.6)$ & $15(37.5)$ & \\
\hline \multirow{5}{*}{ T stage $^{\ddagger}$} & 0 & $2(9.1)$ & $8(20.0)$ & \multirow{5}{*}{0.363} \\
\hline & 1 & $1(4.5)$ & $2(5.0)$ & \\
\hline & 2 & $3(13.6)$ & $9(22.5)$ & \\
\hline & 3 & 16 (72.7) & 19 (47.5) & \\
\hline & 4 & $0(0)$ & $2(5.0)$ & \\
\hline \multirow{3}{*}{$\mathrm{N}_{\text {stage }}{ }^{\ddagger}$} & 0 & 15 (58.2) & $25(62.5)$ & \multirow{3}{*}{0.139} \\
\hline & 1 & $2(9.1)$ & 11 (27.5) & \\
\hline & 2 & 5 (22.7) & $4(10.0)$ & \\
\hline \multirow{4}{*}{ TNM stage $^{\ddagger}$} & 0 & $2(9.1)$ & 7 (17.5) & \multirow{4}{*}{0.474} \\
\hline & 1 & $2(9.1)$ & 7 (17.5) & \\
\hline & 2 & $11(50.0)$ & $13(32.5)$ & \\
\hline & 3 & $7(31.8)$ & $13(32.5)$ & \\
\hline $\begin{array}{l}\text { Duration of ileostomy closure } \\
\text { (month) }^{\beta}\end{array}$ & & $6(4-9)$ & $5(4-7)$ & 0.564 \\
\hline
\end{tabular}

\begin{tabular}{|c|c|c|}
\hline Variable & & Value \\
\hline \multirow{2}{*}{ Type of anastomosis ${ }^{\dagger}$} & Hand-sewn & $9(14.5)$ \\
\hline & Stapled & $53(85.5)$ \\
\hline latrogenic injuryキ & & $2(3.2)$ \\
\hline \multirow{2}{*}{ Complication $^{\ddagger}$} & Yes & $24(38.7)$ \\
\hline & No & $38(61.3)$ \\
\hline \multirow{4}{*}{ Clavien-Dindo grade ${ }^{\ddagger}$} & 0 & $41(66.1)$ \\
\hline & 1 & $9(14.5)$ \\
\hline & 2 & $10(16.1)$ \\
\hline & 3 & $2(3.2)$ \\
\hline \multicolumn{2}{|l|}{ Oral feeding (day) ${ }^{\beta}$} & $2(1-3)$ \\
\hline \multicolumn{2}{|l|}{$\mathrm{LOH}\left(\right.$ day) ${ }^{\beta}$} & $6(4-7)$ \\
\hline \multicolumn{3}{|c|}{$\begin{array}{l}{ }^{*}: n(\%),{ }^{\beta}: \text { median (IQR) } \\
\text { IQR: Interquartile range, LOH: Length of hospital stay }\end{array}$} \\
\hline
\end{tabular}

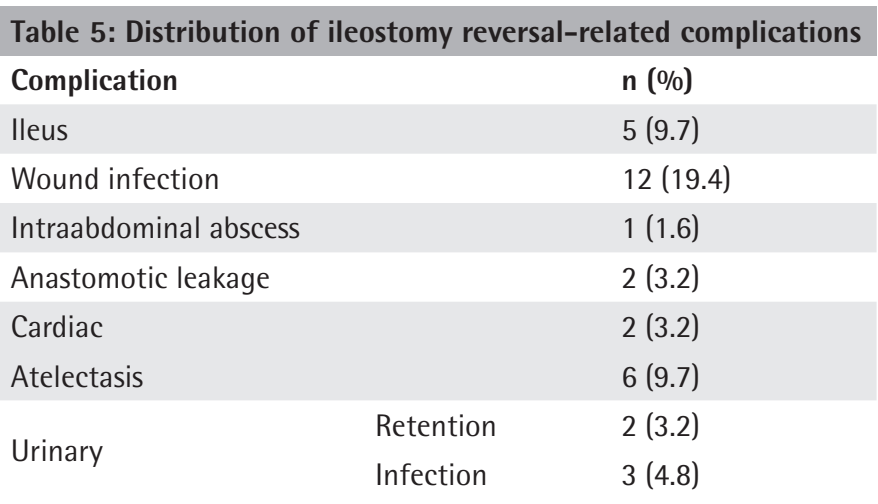

Considering all these studies with different time limits, the optimum timing based on the development of complications remains controversial (14).

According to the predetermined time limits, the groupings may be another critical issue for these controversial outcomes. 


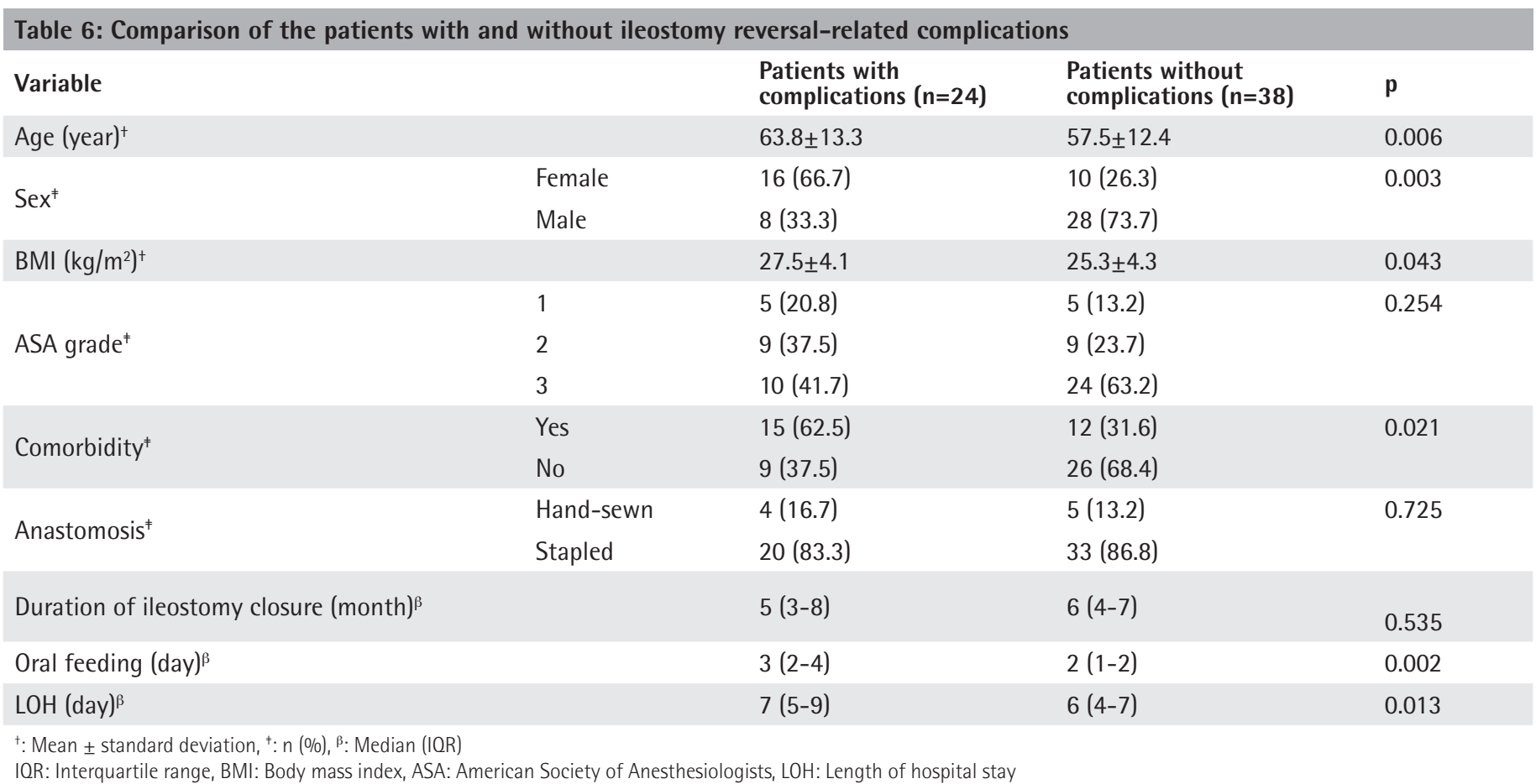

\begin{tabular}{|c|c|c|c|c|c|}
\hline Variable & & Overall $(n=62)$ & $\begin{array}{l}\text { lleostomy closure }<6 \\
\text { months }(n=32)\end{array}$ & $\begin{array}{l}\text { Ileostomy closure } \geq 6 \\
\text { months }(n=30)\end{array}$ & $\mathbf{p}$ \\
\hline Duration (month) ${ }^{\beta}$ & & & $4(3-5)$ & $7(6-9)$ & \\
\hline \multirow{2}{*}{ Ileostomy-related complications ${ }^{\dagger}$} & Yes & $22(35.5)$ & $10(31.2)$ & $12(40.0)$ & \multirow{2}{*}{0.597} \\
\hline & No & $40(64.5)$ & $22(68.8)$ & $18(60.0)$ & \\
\hline \multirow{2}{*}{ Ileostomy reversal-related complications ${ }^{\ddagger}$} & Yes & $24(38.7)$ & $13(40.6)$ & $11(36.7)$ & \multirow{2}{*}{0.799} \\
\hline & No & $38(61.3)$ & $19(59.4)$ & $19(63.3)$ & \\
\hline
\end{tabular}

${ }^{+}: n(\%),{ }^{\beta}:$ Median (IQR)

IQR: Interquartile range

In Abdalla and Scarpinata's study's (9), they compared the patients who had early ( $<6$ months) and late ( $>6$ months) loop ileostomy closure. They found significantly lower postoperative complications in the early group, contrary to our results. But, the mean times were 3.8 and 12.8 months in these groups. The significant difference in the mean times may be the reason for this disparity.

A comparison of the studies based only on the development of complications may prevent performing more powerful analyses. Evaluation of several outcomes, including cost, additional economic burden for the patients, quality of life, bowel dysfunction, and ileostomy-related problems, may be essential to analyze this issue in detail $(7,8,13,15,19)$. Due to our study's retrospective design, we could not analyze the cost and quality of life. Therefore, prospective studies evaluating these factors are needed to determine the optimum timing for ileostomy closure.
Several studies reported no significant impact of the closure time on the development of ileostomy-related complications $(13,15)$. In Zhen et al. $(13)$, the incidence of these complications was $16.5 \%$ and $17.1 \%$ in patients with the ileostomy closure $<1$ month and $>6$ months, respectively. In Li and Ozuner's study (4), the authors analyzed the effect of timing with the threshold limit of 3 months. In their study, there was no difference between the groups. Although they thought that early closure ( $<3$ months) reduces the ileostomy-related complications, there have been other reviews reporting the higher ileostomyrelated complications as the duration increases $(14,20,21)$. A meta-analysis showed a higher incidence of ileostomy-related complications, including stomal ulcer, skin irritation, and high volume output, in patients with late ileostomy closure (defined as $\geq 50$ days after ileostomy) (14). But, recently published a randomized controlled trial was terminated due to higher postoperative morbidity in the early closure group (<30 days) (10). We also showed no difference in ileostomy- 
related complications between the groups as $<6$ months and $\geq$ six months. So, we can conclude that it is impossible to find the optimum timing for ileostomy closure, considering only postoperative complications.

\section{Study Limitation}

The retrospective design and small patient group were the main limitations of the study.

\section{Conclusion}

Our study showed that the timing of ileostomy closure did not influence ileostomy-related and ileostomy reversal-related complications. Age was a significant variable for ileostomyrelated complications. Female sex, obesity, and comorbidity were associated with ileostomy reversal-related complications. The use of different time limits and exploration of the extra parameters, including costs and quality of life, may lead to more significant conclusions in future prospective randomized studies.

\section{Ethics}

Ethics Committee Approval: The local ethical committee approved the study (Ethical Committee for Clinical Studies, Karadeniz Technical University, Faculty of Medicine, 2020/273).

Informed Consent: The patients' written consent could not be taken due to the retrospective design of the study and the anonymity of data.

Peer-reviewed: Externally peer-reviewed.

\section{Authorship Contributions}

Concept: M.A.U., A.B.Ç., Design: M.A.U., A.B.Ç., Data Collection or Processing: M.A.U., A.B.Ç., Analysis or Interpretation: M.A.U., A.B.Ç., Literature Search: M.A.U., A.B.Ç., Writing: M.A.U., A.B.Ç.

Conflict of Interest: No conflict of interest was declared by the authors.

Financial Disclosure: The authors declared that this study received no financial support.

\section{References}

1. Poskus $E_{1}$ Kildusis $E_{1}$ Smolskas $E_{1}$ et al. Complications after Loop lleostomy Closure: A Retrospective Analysis of 132 Patients. Viszeralmedizin. 2014;30:276-280.

2. Choi YJ, Kwak JM, Ha N, et al. Clinical Outcomes of Ileostomy Closure According to Timing During Adjuvant Chemotherapy After Rectal Cancer
Surgery. Ann Coloproctol. 2019;35:187-193.

3. Copăescu C, Smeu B, Catanescu E, et al. Early Laparoscopic Ileostomy Reversal After Rectal Cancer Surgery - Technique and Outcomes. Chirurgia (Bucur). 2019;114:392-400.

4. Li W, Ozuner G. Does the timing of loop ileostomy closure affect outcome: A case-matched study. Int J Surg. 2017;43:52-55.

5. Chow A, Tilney HS, Paraskeva $P$, et al. The morbidity surrounding reversal of defunctioning ileostomies: a systematic review of 48 studies including 6,107 cases. Int J Colorectal Dis. 2009;24:711-723.

6. Sier MF, van Gelder L, Ubbink DT, et al. Factors affecting timing of closure and non-reversal of temporary ileostomies. Int J Colorectal Dis. 2015;30:1185-1192.

7. Keane C, Park J, Öberg S, et al. Functional outcomes from a randomized trial of early closure of temporary ileostomy after rectal excision for cancer. $\mathrm{Br}$ J Surg. 2019;106:645-652.

8. Gustafsson $\mathrm{CP}$, Gunnarsson U, Dahlstrand U, et al. Loop-ileostomy reversalpatient-related characteristics influencing time to closure. Int J Colorectal Dis. 2018;33:593-600.

9. Abdalla S, Scarpinata R. Early and Late Closure of Loop lleostomies: A Retrospective Comparative Outcomes Analysis. Ostomy Wound Manage. 2018;64:30-35.

10. Bausys A, Kuliavas J, Dulskas $A$, et al. Early versus standard closure of temporary ileostomy in patients with rectal cancer: A randomized controlled trial. J Surg Oncol. 2019;120:294-299.

11. Bakx $R$, Busch $O R$, van Geldere $D$, et al. Feasibility of early closure of loop ileostomies: a pilot study. Dis Colon Rectum. 2003;46:1680-1684.

12. Perez RO, Habr-Gama A, Seid VE, et al. Loop ileostomy morbidity: timing of closure matters. Dis Colon Rectum. 2006;49:1539-1545.

13. Zhen L, Wang $Y$, Zhang $Z$, et al. Effectiveness between early and late temporary ileostomy closure in patients with rectal cancer: A prospective study. Curr Probl Cancer. 2017;41:231-240.

14. Wang $L$, Chen $X$, Liao $C$, et al. Early versus late closure of temporary ileostomy after rectal cancer surgery: a meta-analysis. Surg Today. 2021;51:463-471.

15. Robertson J, Linkhorn $H$, Vather $R$, et al. Cost analysis of early versus delayed Ioop ileostomy closure: a case-matched study. Dig Surg. 2015;32:166-172.

16. Danielsen AK, Park J, Jansen JE, et al. Early Closure of a Temporary lleostomy in Patients With Rectal Cancer: A Multicenter Randomized Controlled Trial. Ann Surg. 2017;265:284-290.

17. Echazarreta-Gallego $E$, Elía-Guedea $M$, Córdoba-Díaz de Laspra $E$, et al. Defunctioning ileostomy. Is an early closure safe? Int J Colorectal Dis. 2016;31:771-773.

18. Tulchinsky $H$, Shacham-Shmueli E, Klausner JM, et al. Should a loop ileostomy closure in rectal cancer patients be done during or after adjuvant chemotherapy? J Surg Oncol. 2014;109:266-269.

19. Herrle F, Sandra-Petrescu F, Weiss C, et al. Quality of Life and Timing of Stoma Closure in Patients With Rectal Cancer Undergoing Low Anterior Resection With Diverting Stoma: A Multicenter Longitudinal Observational Study. Dis Colon Rectum. 2016;59:281-290.

20. Memon $S$, Heriot AG, Atkin CE, et al. Facilitated early ileostomy closure after rectal cancer surgery: a case-matched study. Tech Coloproctol. 2012;16:285-290.

21. Robertson JP, Puckett J, Vather R, et al. Early closure of temporary loop ileostomies: a systematic review. Ostomy Wound Manage. 2015;61:50-57. 